\title{
Pembelajaran Flashback Berbasis Bahan Ajar Sejarah Lokal Untuk Membentuk Kesadaran Sejarah Siswa
}

\author{
Abdul Rasyad \\ Universitas Hamzanwadi \\ rasyad.iis@hamzanwadi.ac.id
}

\begin{abstract}
Abstrak
Penelitian ini bertujuan untuk mengetahui implementasi produk pendekatan pembelajaran flashback berbahan ajan sejarah lokal dapat menumbuhkembangkan kesadaran sejarah siswa SMA. Pada penelitian tahun ke-1 telah dihasilkan kebutuhan sekolah pada bahan ajar berbasis sejarah lokal dalam pembelajaran sejarah dan bahan ajar yang memuat tentang pendekatan pembelajaran flashback berbasis bahan ajar sejarah lokal. Penelitian ini dilakukan di 3 (tiga) SMA di Kabupaten Lombok Timur. Penelitian ini merupakan penelitian pengembangan dimana tahap dilakukan melalui tahapan yaitu; studi pendahuluan; pengembangan desain pendekatan pembelajaran dan bahan ajar, uji coba produk; dan diseminasi. Penelitian ini dilakuakan dengan model Penelitian Tindakan Kelas pada 3 (tiga) SMA di Kabupaten Lombok Timur. Hasil penelitian dianalisis menggunakan statistik deskriptif dimana dalam melakukan analisis data merujuk pada komponen yaitu reduksi data, penyajian data, dan verifikasi data. Hasil penelitian menunjukkan bahwa dalam kegiatan pembelajaran dengan menggunakan pendekatan pembelajaran flashback berbasis bahan ajar sejarah lokal berada pada level baik. Data aktivitas siswa menunjukkan $75 \%$ siswa aktif dalam pembelajaran dengan kategori baik dan dari 20 item data obeservasi yang dilakukan untuk guru menghasilkan 19 item telah dilaksanakan guru. Siswa memberikan respon yang variatif dimana analisis terhadap respon siswa menunjukkan $25 \%$ sangat setuju, $75 \%$ setuju. Data hasil kerja siswa menunjukkan bahwa terjadi peningkatan wawasan ilmu dan kesadaran sejarah serta kemampuan menjawab keterkaitan materi ajar dengan kehidupan nyata. Adapun guru memperlihatkan pemahaman baik terhadap keterkaitan antara bahan ajar dengan kemampuan menjelaskan materi dengan baik. Bahan ajar yang telah dikembangkan sangat menarik dan sangat relevan menambah wawasan guru dan siswa terutama dalam menumbuhkembangkan kesadaran sejarah siswa.
\end{abstract}

Kata Kunci: Pembelajaran Flashback, Bahan Ajar, Sejarah Lokal, Kesadaran Sejarah

\begin{abstract}
This study aims to find out the implementation of flashback learning approach products that was made from local history teaching that able to raise historical awareness of high school students. In the first year research, schools require local history-based on teaching history and teaching materials which contains flashback learning approaches based on local history. This research was conducted in 3 (three) high schools in East Lombok Regency. This research is a development research where the stage is carried out through several stages such as; preliminary studies; development of design of learning approach and teaching materials, product testing; and dissemination. This study was conducted with a Class Action Research model in 3 (three) high schools in East Lombok Regency. The results of the study were analyzed using descriptive statistics in which data analysis refers to components namely data reduction, data presentation, and data verification. The results showed that learning
\end{abstract}


activities using flashback learning approach based on local history were at a good level. Student activity data shows that $75 \%$ of students are active to learn and they are categorised as good and from 20 items of observation data which were conducted for teachers produce 19 items that have been implemented by the teacher. Students give a varied response where the analysis of student responses shows $25 \%$ strongly agree, $75 \%$ agree. While, Student work data shows that there is an increase of knowledge and historical awareness as well as the ability to answer the relevance of teaching material with real life. The teacher shows a good understanding of the relationship between teaching materials and their ability to explain the material well. Teaching materials that have been developed are very interesting and very relevant to increase understanding of teachers and students, especially in raising students' historical awareness.

Keywords: Flashback Learning Approach, Teaching Materials, Local History, Historical Awareness

\section{Pendahuluan}

Pembelajaran sejarah memiliki peran sentral dalam membentuk watak dan kepribadian siswa. Untuk itu pembelajaran sejarah di sekolah hendaknya terus-menerus dikembangkan sehingga tujuan pembelajaran sejarah untuk membentuk watak dan kepribadian siswa dapat tercapai. Pembelajaran sejarah sangat penting dalam membentuk watak dan kepribadian siswa. Oleh sebab itu pembelajaran sejarah sering disebut sebagai transfer of value, yaitu pembelajaran tentang nilai, moral, dan spiritual.

Pembelajaran sejarah sangat penting memperhatikan sumber belajar yang berasal dari lokalitas. Artinya, pembelajaran sejarah bertolak dari peristiwa lokal untuk memahami konteks yang lebih luas. Sumber belajar yang sifatnya lokalitas tersebut berupa sejarah lokal. Sejarah lokal merupakan kajian sejarah yang berkisar pada peristiwa-peristiwa lokal yang ada pada masyarakat yang lingkupnya terbatas. Sejarah lokal sebagai salah satu bidang kajian dalam ilmu sejarah sangat penting untuk dipelajari. Hal ini mengingat pentingnya pemahaman nasional yang bebasis pemahaman lokal untuk dikembangkan. Apalagi mengingat bangsa Indonesia yang terdiri dari berbagai suku yang tersebar di seluruh pelosok Indonesia. Kekayaan tentang sejarah lokal tersebut telah memberikan warna terhadap pandangan berbangsa dan bernegara bangsa Indonesia.

Kekayaan sejarah lokal tersebut sangat penting dikembangkan dalam konteks pengembangan pembelajaran di sekolah. Pengembangan tersebut hendaknya diorientasikan untuk menjawab tantangan dalam pembelajaran sejarah. Dimana pembelajaran sejarah harus secara berkesinambungan mampu dibuat inovasi dan kreasi dalam pengembangan 
pendekatan pembelajaran. Salah satu pengembangan pendekatan pembelajaran yang dapat dilakukan adalah dengan pendekatan pembelajaran flashback.

Pendekatan pembelajaran flashback dimaksudkan dapat menjadi alternatif dalam pengembangan pendekatan pembelajaran sejarah. Pendekatan pembelajaran ini mengambil sejarah lokal sebagai materi yang dikembangkan. Basis sejarah lokal ini penting karena pendekatan ini mengedepankan pemahaman terhadap peristiwa masa lalu dimana siswa diajak memahami kehidupan lokal di masa lalu seolah-olah terjadi di sekitar siswa. Dengan demikian kesan pembelajaran sejarah sebagai pelajaran hafalan, membosankan, dan kering makna akan berubah menjadi pembelajaran yang bermanfaat, disenangi, dan diminati oleh siswa.

Berdasarkan masalah di atas, maka melalui penelitian ini peneliti akan merancang dan mengembangakan suatu pendekatan pembelajaran yaitu, pendekatan pembelajaran flashback berbasis sejarah lokal dalam upaya menumbuhkembangkan kesadaran sejarah untuk siswa SMA. Bahan ajar yang telah dikembangkan diimplementasikan sebagai upaya untuk memperbaiki kualitas pembelajaran sejarah di SMA. Penelitian ini sangat memungkinkan menjadi solusi bagi pengembangan pembelajaran sejarah dengan tujuan terbentuknya kesadaran sejarah siswa di SMA berbasis sejarah lokal.

Pendekatan pembelajaran dapat diartikan sebagai suatu konsep atau prosedur yang digunakan dalam membahas suatu bahan pelajaran untuk mencapai tujuan pembelajaran (Soedjana, 1986, p. 4). Pendekatan dapat diartikan sebagai titik tolak atau sudut pandang kita terhadap proses pembelajaran. Istilah pendekatan merujuk kepada pandangan terjadinya suatu proses yang sifatnya masih umum. Oleh karenanya strategi dan metode pembelajaran yang digunakan dapat bersumber atau tergantung dari pendekatan tertentu (Sanjaya, 2008, p. 127). Pendekatan dalam penelitian ini adalah pendekatan pembelajaran flasback. Pendekatan flashback adalah pendekatan pembelajaran yang mengajarkan peristiwa masa lalu dan memulainya dari masa sekarang (Khazzaka, 1997). Pendekatan flashback menjadikan masa lalu sebagai latar belakang untuk menjelaskan masalah atas pertanyaanpertanyaan siswa. Peristiwa kekinian yang masih hangat disampaikan kepada siswa kemudian dihubungkan dengan peristiwa masa lalu yang dijelaskan sebagai materi.

Pendekatan flashback berusaha menciptakan perubahan positif dalam sikap siswa terhadap berbagai pelajaran yang termasuk dalam periswtiwa kekinian. Masa lalu dihadirkan melalui apa yang sedang terjadi di masa sekarang. Hal ini sangat mungkin membuat proses 
pembelajaran sejarah lebih bermakna sekaligus akaj meningkatkan citra sejarah di mata siswa, karena pada dasarnya siswa menikmati situasi yang sedang dialami. Tentu saja proses pembelajaran tetap berpegang pada konsep dan fakta yang benar (Erwin, 2008). Pembelajaran sejarah memiliki arti strategis dalam membentuk watak dan kepribadian bangsa yang bermartabat serta pembentukan manusia Indonesia yang memiliki rasa kebangsaan dan cinta tanah air. Artinya, pembentukan kepribadian nasional tidak akan terwujud tanpa adanya pengembangan kesadaran sejarah sebagai sumber inspirasi dan aspirasi dimana pengembangan kepribadian nasional, identitas, dan jati diri dapat berkembang melalui proses sejarah (Musnir, 1999, p. 23).

Dalam penelitian ini bahan ajar yang akan dikembangkan adalah bahan ajar sejarah lokal. Sejarah lokal adalah sejarah suatu tempat, suatu lcality yang batasannya ditentukan oleh perjanjian yang diajukan penluis sejarah (Abdullah, 1996, p. 15). Adapun menurut Widja (Widja, 1989, p. 3) dijelaskan bahwa sejarah lokal merupakan suatu bentuk penulisan sejarah dalam lingkup yang terbatas yang meliputi suatu lokalitas tertentu. Keterbatasan lingkup itu biasanya dikaitkan dengan unsur wilayah (unsur spasial).

Beberapa penelitian yang relevan dengan penelitian ini di antaranya penelitian Putro tentang "Model Pembelajaran Sejarah Untuk Meningkatkan Kesadaran Sejarah Melalui Pendekatan Inkuiri" (Putro, 2012). Penelitian Musadad dengan judul "Model Manajemen Pembelajaran Sejarah Terintegrasi Pendidikan Multikultural untuk Membangun Wawasan Kebangsaan" (Musadad, 2016). Penelitian Hardiana berjudul "Pembelajaran Sejarah Indonesia Berbasis Peristiwa-peristiwa Lokal di Tasikmalaya untuk Meningkatkan Kemampuan Berpikir Kritis" (Hardiana, 2017). PenelitianPratiwi dengan judul "Upaya Meningkatkan Kesadaran Sejarah Nasional Dalam Era Globalisasi” (Pratiwi, 2018). Secara umum penelitian tersebut menjelaskan tentang posisi penting mata pelajaran sejarah dan sejarah lokal dalam pembelajaran sejarah sebagai sumber sejarah, tetapi tidak ada yang secara khusus menjelaskan tentang upaya mendesain sejarah lokal dalam suatu pendekatan pembelajaran tertentu.

Urgensi penelitian ini diharapkan dapat menberikan kontribusi bahwa sejarah lokal sebagai suatu bidang kajian dalam ilmu sejarah yang membahas tentang suatu sejarah masyarakat atau komunitas dengan lokasi yang terbatas dan dibatasi dengan batasan lokasi dan menjadi acuan dalam pengembangan pembelajaran sejarah. Artinya bahan ajar sejarah lokal dapat dimaknai sebagai suatu sumber berlajar yang berasal dari suatu sejarah 
masyarakat atau komunitas tertentu yang dijadikan sebagai bahan untuk mengorganisir pembelajaran sejarah yang baik.

\section{Metode Penelitian}

Penelitian ini merupakan penelitian pengembangan pendidikan yang bertujuan untuk mengembangkan pendekatan pembelajaran flashback berbasis bahan ajar sejarah lokal. Penelitian pengembangan adalah penelitian yang digunakan untuk menghasilkan produk tertentu, dan menguji keefektifan produk tersebut (Sugiyono, 2013, p. 297). Menurut Puslitjaknov model pengembangan merupakan dasar untuk mengembangkan produk yang akan dihasilkan (Putra, 2011). Model pengembangan dapat berupa model prosedural, model konseptual, dan model teoritik. Dalam penelitian pengembangan ini digunakan model prosedural karena dianggap cocok dengan tujuan pengembangan yang ingin dicapai yaitu, untuk menghasilkan suatu produk dan menguji kelayakan produk yang dihasilkan dimana untuk mencapai tujuan tersebut harus melalui langkah-langkah tertentu yang harus dikuti untuk menghasilkan produk tertentu.

\section{Pembahasan}

Kegiatan penelitian dilakukan pada 3 (tiga) SMAN di Kabupaten Lombok Timur, Provinsi Nusa Tenggara Barat mulai bulan Maret-Oktober 2018. Populasi penelitian ini adalah seluruh siswa kelas XI di 3 (tiga) SMAN yaitu SMAN 2 Selong, SMAN 1 Masbagik dan SMAN 1 Terara di Kabupaten Lombok Timur. Sampel penelitian ditentukan menggunakan teknik random sampling. Fokus penelitian ini ditujukan untuk menjawab yaitu; (1) Efektifitas pendekatan pembelajaran flashback berbasis bahan ajar sejarah lokal dalam pembelajaran sejarah; dan (2) Mengetahui pengaruh pendekatan pembelajaran flashback berbasis bahan ajar sejarah lokal dalam pembelajaran sejarah untuk menumbuhkembangkan kesadaran sejarah siswa.

Selain dengan kuesioner, observasi dan wawancara telah dilakukan untuk menggali kebenaran informasi yang telah diberikan oleh responden pada kuesioner. Data yang terkumpul melalui kuesioner dianalisis dengan metode kuantitatif sedangkan data yang terkumpul melalui observasi dan wawancara dianalisis dengan metode kualitatif. Kesimpulan penelitian ditarik berdasarkan data kuantitatif sedangkan data kualitatif diperlakukan sebagai data sekunder. Hasil tes awal dan tes akhir dibandingkan untuk 
mengetahui efektifitas pendekatan pembelajaran flashback berbasis bahan ajar sejarah lokal dalam pembelajaran sejarah.

Pada penelitian tahun pertama yang dilakukan akan pengumpulan data kebutuhan penyusunan pendekatan pembelajaran flashback dan penyusunan bahan ajar berbasis sejarah lokal. Deskripsi data hasil penelitian tahun pertama dapat dijelaskan pada pembasan berikut ini. Dalam kontek bahan ajar sejarah lokal, beberapa aspek yang menjadi temuan dalam penelitian ini adalah sebagai berikut:

1. Buku atau bahan ajar sejarah sebagai bahan ajar penunjang untuk mata pelajaran sejarah belum ada bahan ajar yang bisa membantu guru dan siswa mengintegrasikan materi ajar dengan sejarah lokal terutama dalam konteks sejarah di Lombok.

2. Kesesuaian bahan ajar dengan kehidupan nyata belum tampak dalam setiap materi yang diberikan. Buku ajar lebih terpusat, jarang bersumber dari lingkungan sekitar siswa.

3. Pengetahuan guru tentang sejarah lokal Lombok belum memadai. Guru belum enunjukkan pengetahuan sejarah lokal, dari guru yang diteliti rata-rata guru sudah memahami tetapi belum sistematis dalam memberikan penjelasan kepada siswa. Di samping itu pengetahuan siswa belum menunjukkan pengetahuan yang mendalam tentang sejarah lokal Lombok.

4. Bahan ajar yang digunakan sebagian besar bahan ajar yang telah tersedia melalui penerbit, guru belum ada yang menyusun bahan ajar sendiri.

5. Kendala-kendala yang dihadapi guru dan siswa dalam pendekatan pembelajaran sejarah yang terkait dengan basis sejarah lokal dilihat berdasarkan hal-hal yaitu; a). Buku/bahan ajar jumlahnya masih terbatas; b). Belum ada bahan ajar sejarah yang bisa menghubungkan antara satu materi ajar sejarah dengan sejarah lokal Lombok; c). Masih kurangngnya wawasan sejarah lokal yang dimililiki oleh guru; d). Siswa kurang berminat terhadap sejarah lokal.

6. Solusi yang diharapkan guru dan siswa dapat dijelaskan yaitu; a). Perlu penambahan bahan ajar sejarah lokal; b). Bahan ajar sebagai bahan ajar pendukung yang bisa membantu guru dan siswa untuk menumbuhkembangkan kesadaran sejarah; c). Pendekatan pembelajaran dan bahan ajar sejarah yang berbasis sejarah lokal untuk meningkatkan kesadaran sejarah siswa.

Adapaun dalam pelaksanaan metode pembelajaran, hal-hla yang ditemukan yaitu; 1). Pendekatan pembelajaran yang digunakan oleh sebagian besar guru masih menggunakan 
pengajaran langsung, belum pernah melaksanakan metode inquiri; 2) Media pembelajaran yang digunakan oleh sebagian besar guru sudah menggunakan media seperti: LCD, peta, peta konsep, atlas, globe, laptop, namun penggunaanya belum maksimal; 3) Metode pembelajaran sejarah yang berbasis sejarah lokal dimana guru dan siswa belum pernah melaksanakan pendekatan pembelajaran flashback berbasis sejarah lokal untuk menumbuhkembangkan kesadaran sejarah siswa.

Kendala-kendala yang dihadapi guru dan siswa dalam pembelajaran sejarah yaitu; 1) Guru dan siswa kesulitan dalam memahami sejarah lokal karena tidak adanya sumber yang memadai; 2) Siswa kurang memiliki motivasi dalam memahami pendekatan guru dalam pembelajaran sejarah; 3) Harapan guru dan siswa bahwa diperlukan pendekatan pembelajaran seperti pendekatan pembelajaran flashback untuk membantu guru dalam mengorganisir pembelajaran di kelas.

Pada tahun kedua ini tahapan penelitian yang dilakukan yaitu, melakukan desiminasi produk penelitian pada tahap kesatu, dimana dilakukan ujicoba implementasi pendekatan pembelajaran flashback berbasis bahan ajar sejarah lokal yang dilakukan melalui penelitian tindakan kelas (PTK) dengan metode kualitatif. Ujicoba dilakukan pada siswa kelas XI SMAN 2 Selong, SMAN 1 Masbagik, dan SMAN 1 Terara di kabupaten Lombok Timur. Ujicoba melalui PTK merupakan tahapan yang dilakukan untuk mengetahui bagaimana pendekatan flashback berbasis bahan ajar sejarah lokal dapat menumbuhkembangkan kesadaran sejarah siswa SMA di kabupaten Lombok Timur. Adapun tahapan yang dilakukan sebagai berikut.

\section{Tahap Ujicoba Melalui PTK}

Ujicoba melalui PTK bertujuan untuk mengetahui pendekatan flashback berbasis bahan ajar sejarah lokal dapat menumbuhkembangkan kesadaran sejarah siswa SMA di kabupaten Lombok Timur. Hasil penelitian menunjukkan bahwa kesadaran sejarah siswa kelas XI SMAN 2 Selong mengalami peningkatan sebesar 19,8\% dari rerata hasil belajar pada siklus I yaitu sebesar 60,5 menjadi 70,6 pada siklus II, dan meningkat menjadi 80,3 pada siklus III. Hal ini menunjukkan bahwa pendekatan pembelajaran flashback berbasis bahan ajar sejarah lokal berhasil meningkatkan kesadaran sejarah pada siswa kelas XI SMAN 2 Selong. Kesadaran sejarah siswa kelas XI SMAN 1 Masbagik mengalami peningkatan sebesar $19 \%$ dari rerata hasil belajar pada siklus I yaitu sebesar 62,5 menjadi 70,6 pada siklus II, dan meningkat menjadi 81,4 pada siklus III. Hal ini menunjukkan bahwa 
pendekatan pembelajaran flashback berbasis bahan ajar sejarah lokal berhasil meningkatkan kesadaran sejarah pada siswa kelas XI SMAN 1 Masbagik. Adapun kesadaran sejarah siswa kelas XI SMAN 1 Terara mengalami peningkatan sebesar 21\% dari rerata hasil belajar pada siklus I yaitu sebesar 61,7 menjadi 73,2 pada siklus II, dan meningkat menjadi 82,4 pada siklus III. Hal ini menunjukkan bahwa pendekatan pembelajaran flashback berbasis bahan ajar sejarah lokal berhasil meningkatkan kesadaran sejarah pada siswa kelas XI SMAN 1 Terara.

Hasil penelitian dianalisis menggunakan deskriptif kualitatif dimana dalam melakukan analisis data merujuk pada komponen yaitu reduksi data, penyajian data, dan verifikasi data. Hasil penelitian menunjukkan bahwa dalam kegiatan pembelajaran dengan menggunakan pendekatan pembelajaran flashback berbasis bahan ajar sejarah lokal berada pada level baik. Data aktivitas siswa menunjukkan $75 \%$ siswa aktif dalam pembelajaran dengan kategori baik dan dari 20 item data observasi yang dilakukan untuk guru menghasilkan 19 item telah dilaksanakan guru. Siswa memberikan respon yang variatif dimana analisis terhadap respon siswa menunjukkan 25\% sangat setuju, $75 \%$ setuju. Data hasil kerja siswa menunjukkan bahwa terjadi peningkatan wawasan ilmu dan kesadaran sejarah serta kemampuan menjawab keterkaitan materi ajar dengan kehidupan nyata. Adapun guru memperlihatkan pemahaman baik terhadap keterkaitan antara bahan ajar dengan kemampuan menjelaskan materi dengan baik. Bahan ajar yang telah dikembangkan sangat menarik dan sangat relevan menambah wawasan guru dan siswa terutama dalam menumbuhkembangkan kesadaran sejarah siswa

Secara kualitatif, pelaksanaan pembelajaran pada setiap tahapan ujicoba menunjukkan aktivitas yang meningkat, siswa semakin memahami cara mempelajari materi pembelajaran, menggunakan pendekatan pembelajaran flashback, dan meningkatkan interaksi antara guru-siswa dan siswa-siswa lainnya serta siswa-media. Secara kuantitatif, data hasil belajar siswa pada materi pembelajaran menggunakan pendekatan pembelajaran flashback berbasis bahan ajar sejarah lokal menunjukkan peningkatan pada setiap tahapan ujicoba dari 3 siklus yang diberikan di masing-masing siswa di setiap sekolah (SMAN). Data pemahaman pembelajaran siswa terutama pada aspek kesadaran sejarah yang ditujukkan berada pada kategori baik.

Sejarah sebagai suatu kajian keilmuan merupakan ilmu yang menjelaskan tentang asal-usul dan perkembangan serta peranan masyarakat pada masa lampau. Pemahaman 
masa lampau tersebut mengandung nilai-nilai kearifan yang dapat digunakan untuk melatih kecerdasan, membentuk sikap, watak dan kepribadian siswa yang dapat menumbuhkan kesadaran sejarah. Mata pelajaran sejarah memiliki arti strategis dalam pembentukan watak dan peradaban bangsa yang bermartabat serta dalam pembentukan manusia Indonesia yang memiliki rasa kebangsaan dan cinta tanah air dalam konteks kesadaran sejarah bangsa. Materi sejarah lokal dapat mengandung nilai-nilai kepahlawanan, keteladanan, kepeloporan, patriotisme, nasionalisme, dan semangat pantang menyerah yang mendasari proses pembentukan watak dan kepribadian peserta didik. Khasanah kebudayaan bangsa melalui bahan ajar sejarah lokal merupakan bahan pendidikan yang mendasar bagi proses pembentukan dan penciptaan peradaban bangsa Indonesia di masa depan. Menanamkan kesadaran persatuan dan persaudaraan serta solidaritas untuk menjadi perekat bangsa melalui sejarah lokal dapat menghindari ancaman disintegrasi bangsa.

Pada prinsipnya untuk membentuk dan mengembangkan kecakapan peserta didik baik itu kecakapan akademik, kesadaran sejarah, dan nasionalisme, posisi sejarah lokal dapat dijadikan sebagai salah satu materi dan tolak ukur dalam melihat cara pandang peserta didik terhadap bangsa dan negara. Menumbuhkan pemahaman peserta didik terhadap proses terbentuknya bangsa Indonesia melalui sejarah yang panjang dan masih berproses sampai masa kini dan masa yang akan datang merupakan kesadaran mendasar dalam memaknai ke-Indoesia-an. Kesadaran sejarah yang menjadi tujuan utama penelitian ini dapat dielaborasi dalam mengelola pembelajaran sejarah melalui bahan ajar sejarah lokal.

Proses pembelajaran dalam hal ini mencakup suasana pembelajaran dan strategi pembelajaran yang digunakan. Pembelajaran sejarah melalui sejarah lokal harus berorientasi pada masa depan. Hal ini mengandung arti bahwa orientasi, atau mungkin lebih tepat perluasan wawasan pengajaran sejarah dapat menekankan aspek masa kelampauannya, diperluas kearah orientasi pengajaran sejarah berwawasan masa depan dengan basis sejarah lokal. Penekanan wawasan pengajaran sejarah pada masa depan ini, pada dasarnya juga sesuai dengan hakekat tujuan pendidikan yang mempersiapkan kehidupan masa depan bagi generasi penerus. Konsep masa lampau adalah guru terbaik bagi masa depan, dapat menjadi salah satu perspektif yang strategis dalam menempatkan konsep wawasan masa depan dalam pengajaran sejarah yang dinamis (Pratiwi, 2018).

\section{Kesimpulan}


Kegiatan pembelajaran dengan menggunakan pendekatan pembelajaran flashback berbasis bahan ajar sejarah lokal berada pada level baik. Data aktivitas siswa menunjukkan 75\% siswa aktif dalam pembelajaran dengan kategori baik dan dari 20 item data obeservasi yang dilakukan untuk guru menghasilkan 19 item telah dilaksanakan guru. Siswa memberikan respon yang variatif dimana analisis terhadap respon siswa menunjukkan $25 \%$ sangat setuju, 75\% setuju. Data hasil kerja siswa menunjukkan bahwa terjadi peningkatan wawasan ilmu dan kesadaran sejarah serta kemampuan menjawab keterkaitan materi ajar dengan kehidupan nyata. Adapun guru memperlihatkan pemahaman baik terhadap keterkaitan antara bahan ajar dengan kemampuan menjelaskan materi dengan baik. Bahan ajar yang telah dikembangkan sangat menarik dan sangat relevan menambah wawasan guru dan siswa terutama dalam menumbuhkembangkan kesadaran sejarah siswa.

\section{Daftar Rujukan}

Abdullah, T. (1996). Sejarah Lokal di Indonesia. Universitas Gadjah Mada Press.

Erwin, T. N. (2008). Pentingnya Pendekatan Flashback dalam Pembelajaran Sejarah. Orasi Ilmiah Pada Pengukuhan Guru Besar Bidang Imu Pendidikan Sejarah.

Hardiana, Y. (2017). Pembelajaran Sejarah Indonesia Berbasis Peristiwa-Peristiwa Lokal di Tasikmalaya untuk Meningkatkan Kemampuan Berpikir Kritis. Historia: Jurnal Pendidik Dan Peneliti Sejarah, 1(1), 41-46.

Khazzaka, J. (1997). Flashback: Comparing Two Approaches to Teaching World History. Social Education, 61(4), 210-214.

Musadad, A. A. (2016). Model Manajemen Pembelajaran Sejarah Terintegrasi Pendidikan Multikultural Untuk Membangun Wawasan Kebangsaan. Paramita: Historical Studies Journal, 25(2), 247-260.

Musnir, D. N. (1999). Arti Penting Kesadaran Sejarah Nasional bagi Warga Bangsa Indonesia. Orasi Ilmiah Pada Pengukuhan Guru Besar Bidang Ilmu Pendidikan Sejarah.

Pratiwi, E. Y. R. (2018). Upaya Meningkatkan Kesadaran Sejarah Nasional Dalam Era Globalisasi. Civic Edu: Jurnal Pendidikan Kewarganegaraan, 2(1), 1-10.

Putra, N. (2011). Research \& Development Penelitian dan Pengembangan: Suatu Pengantar. Raja Grafindo Persada.

Putro, H. P. N. (2012). Model Pembelajaran Sejarah Untuk Meningkatkan Kesadaran Sejarah Melalui Pendekatan Inkuiri. Paramita: Historical Studies Journal, 22(2).

Sanjaya, W. (2008). Strategi Pembelajaran Berorientasi Standar Proses Pendidikan. Kencana Prenada Media Grouf.

Soedjana. (1986). Metode Statistik. Tarsito.

Sugiyono. (2013). Metode Penelitian Kuantitatif, Kualitatif, dan R\&D. Alfabeta. 
Jurnal Humanitas

Vol. 5 No. 2, Juni 2019, hal. 71-81

Widja, I. G. (1989). Widja, I Gde. Sejarah Lokal Suatu Perspektif dalam Pengajaran Sejarah. Proyek Pengembangan Lembaga Pendidikan Tenaga Kependidikan. 